\title{
Parallels between two worlds: Literary science-fiction imagery and transhumanist visions
}

\section{JANA TOMAŠOVIČOVÁ}

DOI: https://doi.org/10.31577/WLS.2021.13.1.3

Transhumanism presents a vision of the future in which accelerating technological progress is likely to surpass human limitations and expand the cognitive, emotional, and physical abilities of people. ${ }^{*}$ This refinement is to be achieved by using today's genetic and information technology as well as further developments in biotechnology, nanotechnology, and artificial intelligence that are expected to arrive in the near future (Bostrom 2018, 92). As one of the more notable participants in the discourse, Nick Bostrom claims that targeted improvement may transform us into beings who may, for instance, live indefinitely and have broader cognitive abilities than any human previously, perfect sensory perception, and access to sensory qualities that are currently completely unknown (38). These kinds of radical refinements produce great expectations but also valid doubts, making in turn this discourse the subject of much discussion. ${ }^{1}$

If we were to research the prerequisites of transhumanist visions, we would have to analyze multiple and multidimensional levels. One level is the anthropological interpretation of man as "an insufficient being" (Gehlen 2009, 83) who is biologically limited in many respects. At the same time, however, this being possesses an uncanny mutability that relentlessly pushes itself toward self-improvement, the overcoming of shortcomings, and a substitution of deficiencies. Another level can be found on the social level. The current zeitgeist of society, where individualization and individual success in social competition are highly prized, provides an ample basis for the spread of transhumanist ideals. The successful integration of individuals into society depends on their performance, skills, and abilities, and therefore the optimization of basic human abilities becomes an avenue to succeeding in a competitive environment (Spreen 2018, 16).

In addition to the anthropological and social levels, modern science prepared the groundwork for transhumanism through genetics in particular. Decoding the human genome allows one to understand the building blocks of life and gradually use gene technology to correct genetic flaws present in the human body (Sýkora 2019). Rapid developments in the field also lay the groundwork for various experimental processes for human refinement. According to some authors, technological progress

* This article was supported by the project APVV-17-0064 "Analysis of multidimensional forms of trans- and post-humanism". 
is increasing exponentially and is another important precondition for transhumanism, so one can presuppose that soon mankind will reach a point when technological progress has become so rapid and broad in scope that with our current abilities we will be unable to comprehend it (Kurzweil 2016, 174). While one line of transhumanism places the main emphasis on human refinement through genetic engineering, others go in the direction of technological perfection, over the course of which mankind would see evolutionary "imperfections" corrected - including even mortality - perhaps to a degree where humans achieve incorporeal existence as digital data or some sort of superintelligence (Kurzweil 2016, 211; Bostrom 2020, 41-79).

Besides the listed prerequisites for transhumanist developments, one should also keep in mind numerous inspirations stemming from science fiction, the figurative speech of which, in connection with anticipated technological developments, provides strong stimuli for transhumanist visions. The language of transhumanism is not entirely alien to the general public, as representations of human optimization efforts are well-known from science-fiction media and are a cultural touchstone in our culture.

This article focuses on the Foundation series of science fiction, written by one of the best-known creators of the genre, Isaac Asimov (1920-1992). ${ }^{2}$ His first short stories dealing with the Foundation appeared in 1942 in Astounding Science Fiction magazine, which was then run by John W. Campbell and which focused on science fiction by young authors. Under Campbell's stewardship, the quality of the magazine improved substantially; he placed an emphasis on the accuracy of the scientific and technical information that authors dealt with. As most authors at the magazine had an education in the natural sciences (for instance, Asimov had a doctorate in biochemistry), they were quickly able to comply with Campbell's requirements and integrate new discoveries from the natural sciences into the diegetic level of their texts. The period between 1938 and 1946, when the magazine Astounding Science Fiction enjoyed its greatest fame, is considered the "Golden Age of Science Fiction". It was during this time that the magazine published Asimov's work, and so his beginnings can be dated back to this period. By virtue of his work, Asimov quickly gained credibility among authors, reaching a status alongside names such as Robert A. Heinlein and Alfred E. van Vogt. In addition to popular short stories about robots, ${ }^{4}$ he published his first stories about the Foundation, which he then published in book form as a trilogy titled Foundation (1951), Foundation and Empire (1952), and Second Foundation (1953). In his series, he deals with the theme of the impending demise of the galactic Empire and the influence of that on social developments. In addition to mathematical and technical knowledge, an important place is given to the social, historical, and psychological sciences. Through the inclusion of these, Asimov substantially broadened the scope of topics and issues that science fiction deals with (Allen 1977, 7). It is likely that this contributed to Asimov receiving a special Hugo Award for Best All-Time Series in 1966 for the Foundation series. In the 1980s, he returned to the topic and published four more sequels.

This article focuses on three motifs present in the original trilogy of Asimov's Foundation series and examines to what degree key elements present in science-fiction 
literature directly mirror the concept of transhumanism, and whether parallels or differences can be identified between both discourses.

\section{A VISION OF THE FUTURE AND A CRITICAL PERSPECTIVE ON THE PRESENT}

Constant scientific and technological progress play a great role in science-fiction literature. Literary visions of the future, which science fiction presents, are not merely arbitrary games of the author's fantasy; rather, they rest on scientific and technological understanding, which becomes an inseparable component of fantastical storytelling. ${ }^{5}$ Science fiction creates a vision of the future which takes place in a specific space-time known as the chronotope, which usually happens in the far future and is located in inaccessible or uncharted realms where time and space form a meaningful whole. ${ }^{6}$ In this space-time, the author develops, whether as a utopia or a dystopia, new visions of further scientific and technical as well as moral, social, and political operations of society. One could claim that the key feature of science fiction is an intertwining of understanding and prediction and of fact and vision, and thus conclude that the genre has a visionary function.

In his study, Johannes Rüster points out that science fiction is visionary and subversive $(2018,147)$. What does this mean? Literary visions of the future are usually contradictory to the actual present and a challenge, disturbance, or undermining of its standard constellations, preferred classifications, and established forms of thought. For a new vision of the future, the old order is insufficient, and thus a differentiation from it must be made. It is exactly thanks to this moment that science fiction is later able to retroactively conjure up a critical perspective on the present and guide further development. Science fiction is not merely imagination supported by scientific and technical knowledge; its vision of the future becomes powerful material for a reconsideration of the really existing and non-literary present. It is worth noting that the dynamic often transfers into a fictional space-time; the creation of a vision of a new social order is preceded either by a direct existential threat or a slow decay of the current order, or the new order provides a retrospective mirror to the still-existing yet slowly dissolving system.

This dynamic between visions of the future and a critical reflection, which is one of the characteristics of the science-fiction genre, can be identified in Asimov's Foundation trilogy in two lines of inquiry. The first line is directly in a fictional space-time. Preceding the Foundation was the identification of the dissolution of the old order, represented by the Empire. The forces behind the decay of the Empire were chiefly inertia, despotism, and the unjust distribution of goods, which had led to a suppression of curiosity, the expansion of bureaucracy, and a deepening of dependence. The vision of a new and more stable and cleverly designed order is built upon a critical evaluation of the drawbacks of the Empire and the preservation of existing scientific and technical knowledge. This is the basis and most important motivating factor for the creation of the new order in Foundation. Similarly, its rapid growth and successful surmounting of crises become serious grounds for reconsideration in the decaying Empire. The second and more important line can be observed in the extra-liter- 
ary time-space. A vision of a stronger and more perfect social system which Asimov creates in his science-fiction story can be interpreted as a reaction to the collapses of various empires throughout history. Asimov took the example of the rise and fall of the Roman Empire, as depicted in the historical works by Edward Gibbon. ${ }^{7}$ Asimov's vision of the founding of a new social order on a solid basis, such as an encyclopedia containing the sum total of discovered knowledge, is the sign of a well-thought-out founding act. Even though this vision of a society based on knowledge is not new within the framework of sociopolitical conceptions or philosophical thought experiments about an ideal state, it is nonetheless a strong impulse for the critical re-evaluation of the current operation of social systems. In both presented lines (fictional and extra-literary space-time) we can observe the effectiveness of key aspects of science-fiction literature.

If science fiction is simultaneously visionary and subversive, then the question arises as to whether these elements are also inherent to transhumanism, the rhetoric of which comes very close to science fiction. The introduction of the present article hinted that transhumanism also works with visions and prognoses for the future. Even though the future has almost always been fertile soil for various scenarios where human fantasy was allowed to run wild, it is still necessary to create scenarios of such predominantly symbolical or eschatological character and clearly divide them from scenarios that claim factual grounding and plausibility. Transhumanism creates visions of the future, but, according to Bostrom, these are realistic visions rather than fantastical images (Bostrom 2018, 10). Despite the fact that realistic predictions of future developments are usually incomplete due to our limited knowledge, this does not mean that we should abandon them completely; after all, many planning strategies have already proven themselves useful and sensible in current practice. According to Bostrom, exact knowledge and relevant arguments provide a sufficient framework for the creation of plausible and realistic visions of the future without having to concede the future of mankind to speculation and fantasy (13). Bostrom presents multiple scenarios for the future of mankind, and it is important to acknowledge the perspective with which he draws up his visions. Above all, his is a technocentric perspective (22) that asserts that nearly all substantial aspects of social and private life are directly or indirectly affected by technology. Bostrom posits that current technology and its rapid advancement are the greatest existential threats to mankind in the 21 st century, and in one scenario they may be the cause of its extinction (22). ${ }^{8}$ This confrontation has, not only for Bostrom, become reason to formulate new visions of the future. What transhumanist visions have in common across the entire discourse is that the same technology which creates the risks, may on the other hand help us reduce these risks (25). As an example, Bostrom theorizes the creation of superintelligence, which may well threaten the existence of the species, but which may also increase mankind's chances of survival if it is capable of harnessing super-intelligent planning (46).

From these thoughts, one can conclude that visions of the future and a critical reflection on the present are characteristic features of both science-fiction and transhumanist discourse. Science fiction provides transhumanism with many literary 
images as inspiration for the creation of transhumanist visions. However, whereas literary visions mostly take on a fantastical shape, which to a great degree is the result of the artist's imagination, transhumanist visions endeavor to achieve the character of realistic images, capturing the future development of mankind and appealing to current knowledge, including that of science and technology. Literary and transhumanist discourse has the ability to incite reflections on the present. Reflection and discussion triggered by transhumanist discourse, however, is much greater in scope than that triggered by science-fiction visions and also has greater reach and relevance to technological optimization.

\section{BIG DATA ANALYSIS AND ARTIFICIAL INTELLIGENCE}

Asimov integrated one especially interesting element into his Foundation series. This was the method by which one of its protagonists, Hari Seldon, predicted the downfall of the Empire. Seldon, as the founder of psychohistory, studied human behavior. He followed the reactions of large groups of people and great societies to various social, cultural, and economic stimuli. One important prerequisite for his research was that the relevant human societies were large enough for the data collection to be suitable for research purposes and that the societal reactions were spontaneous (Asimov 2010, 25). The collected data allowed him to make predictions of future events and developments in social and economic arenas; indeed: "The reaction of one man could be forecast by no known mathematics; the reaction of a billion is something else again" (Asimov 2010, 205).

As early as in the middle of the twentieth century, Asimov ascribed great significance to data collection and processing, which can result in detailed analyses and predictions of fundamental movements in multiple fields in the near future. His protagonist anticipated the collapse of the Empire based on what we might call, in agreement with Tom Boellstorff, "big data" $(2014,109)$. Big data refers to huge sets of information from varied aspects of life which, with their scope, speed, and variety surpass the abilities of common software to capture and process it (Manovich 2014, 65). In the age of digital technology, the sources of data collection themselves constantly increase in size.

Big data analysis has become one of the strategic factors in the operation of current society. Research into this field has undergone substantial differentiation in recent years, and it is worthwhile looking in detail at two closely related aspects in particular where connections to transhumanist discourse can be found. For one thing, huge databases have inspired research into their effective practical uses. Even though big data analysis was initially used mostly for economic prognoses and models (Berry 2014, 47), after the addition of data from the humanities and social media there gradually began to emerge studies into trends, models, and developments in culture and society. Lev Manovich $(2014,67)$ asserts that scientists have gained access to such a huge amount of data that it has permitted a broadening of research space into humanities and social sciences, initiated new forms of research into cultural formulas and social movements, and simultaneously activated the interdisciplinary dimension of research. On the other hand, the processing and analysis of data has required in- 
creasingly effective and sophisticated analytic tools. Besides techniques such as data classification and text and predictive analysis, new techniques are being constantly developed and refined, including artificial intelligence. One can thus observe that big data and methods of data analysis are interconnected in terms of use. Requirements for data use stimulate development of new analytic methods which then allow for new innovative applications.

This does not mean however, that the development of one or the other field lacks its own dynamic. As Bogumiła Suwara points out, it is important to differentiate between work "with" digital media and work "within" digital media $(2016,97)$. One can observe that in the field of data analysis application there are numerous discussions on various important social topics, such as the social repercussions of big data research, monopoly on access to data, privacy protections, the structure of a new society, and mechanisms of social control (Galloway and Thacker 2014; Deleuze 1993, 254-262; Manovich 2014, 65-83). One can also observe a broadly diversified and rapid development in the field of digital systems. New algorithms for artificial intelligence (AI) are being developed around the clock, and with machine learning and in specific tasks its performance is already surpassing human efforts. AI has already beaten world champions at various strategic games, be it chess, Scrabble, or Jeopardy, and it can also provide global email communication, administer banking systems, and drive autonomous cars (Bostrom 2020, 27-33). Even though these performances are bound tightly to specifically set goals, they give scientists hope that in the near future AI could achieve the level of a general form of intelligence which is capable of performing all intellectual activities much like a human. From there, transhumanist visionaries see only a step to superintelligence, which would surpass human cognitive abilities in practically all fields (41). In such an event, the speed of data processing for such a huge amount of data and resulting cognitive results would be incomprehensible for humans (Lacko 2020).

Big data analysis was a key factor in Asimov's literary storytelling in the Foundation series. It is equally important to the functioning of current society, where more and more reliance is placed on the analysis of a great amount of data by AI which will probably be performed by superintelligence in the future. While Asimov's literary vision is based on natural human intelligence, capable of analyzing large amounts of data using mathematics, the best-known transhumanist vision is built around the idea of machine superintelligence, which is capable of analyzing exponentially more data using algorithms operating on the basis of mathematics and informatics. Both visions intersect at the topic of data processing - which is related to the level of intelligence, rationality, and mathematics available to the processor - and they confirm the importance of that topic to society. The question remains open as to whether this task will be handled by human intelligence, AI, or superintelligence in the future. Human intelligence is able to adapt and evolve naturally, but evolutionary experience shows that this process is slow. AI has the benefit of exponential growth of processing power (Kurzweil 2016, 48-54), which is visible today in some fields where it surpasses human efforts. Even though creating or surpassing the general level of human intelligence is not entirely easy, the transhumanist vision of creating superintelligence, 
regardless of whether it ultimately bears fruit or not, will continue to be pursued simply because human ability to analyze large amounts of data is so limited and efforts to make the process more efficient will always seem worthwhile.

\section{COEXISTENCE WITH THOSE DIFFERENT FROM US}

Based on an analysis of sociocultural and economic movements, the protagonist Hari Seldon predicted the demise of the Empire and the gradual growth of influence of the Foundation. In his analyses, he predicted many crises that the Foundation would face but successfully overcome. However, he failed to predict one factor, which was the arrival of a mutant with superhuman mental abilities. This mutant was capable of controlling other people's emotions and turning enemies and opponents into allies. His influence solidified at the expense of the Foundation but without bloodshed. Asimov included the following thought in his work: "If the Mule's descendants inherit his mental powers - You see? Homo sapiens could not compete. There would be a new dominant race - a new aristocracy - with Homo sapiens demoted to slave labor as an inferior race. Isn't that so?" (Asimov 2010, 394).

Here Asimov broached a topic in his novel which continues to resonate in transhumanist discourse. According to transhumanist scenarios, it may be possible to achieve superintelligence not only through a refinement of AI, as described in the previous section, but also through the refinement of human intelligence. For the purposes of increasing human cognitive abilities, there are multiple paths one can take, from pharmacological substances through to neurotechnology and genetic engineering. ${ }^{9}$ Genome editing, which allows for the targeted rewriting of genetic information with fairly great accuracy, shows especially great promise as a tool for the improvement of cognitive abilities, albeit not without ethical questions. Transhumanists predict that in the coming decades, genetic modification will become commonplace, leading to the emergence of a more perfect human. According to Bostrom, the potential presented by biological refinement is sufficient for weaker forms of superintelligence to emerge $(2020,69)$. Moreover, in the course of evolution the intelligence of man has constantly improved compared to his predecessors, so there is no reason to assume that Homo sapiens is the best cognitive system (69). Bostrom views the achieving of at least a lesser form of superintelligence through the biotechnological refinement of human cognitive abilities as realistic. He refers to "weaker forms" because the improvement of biological systems is significantly slower than systems of AI.

With rising human abilities, concerns surface regarding the potential discrimination and stigmatization of the unrefined population as well as concerns about growing inequality. Asimov expresses similar worries in his novels. He appears to defuse these worries with the superhuman mutant simply not conceiving offspring who would bring his abilities to future generations. In the meantime, however, the population of the Second Foundation secretly lived with similar mental capabilities as the mutant. Luckily their actions were not of a conquering but rather a stabilizing nature. Transhumanists do not avoid concerns of discrimination; they claim that potential social problems require social solutions (Bostrom 2018, 98). This means that simi- 
larly to how society in the present attempts to deal with inequality using social regulation and laws, there will be a need for adequate social mechanisms in the future. Also today, inequality exists due to social and genetic factors, i.e., inequalities caused on the one hand by social background and status and on the other by genetic traits, which present themselves as varied talents and physical markers. Here the efforts of democratic society are to find and apply effective protective and regulatory systems so that the worst possible position would still be acceptable for anyone (Rawls $2007,78)$. The society of the future would face a similar task with regard to refined humans. Bostrom does not predict society automatically devolving into slavery, but rather sees the need for a more intensive search for societal solutions to emergent factors $(2018,97)$.

This problem can be viewed from the perspective of mutual coexistence with those different from us (i.e., accepting variety and differences) and phenomenological philosophy provides us with a rich tapestry of analyses in this direction, ${ }^{10}$ but equally evocative are the thoughts of contemporary Italian philosopher Roberto Esposito (2004) on the phenomenon of immunity, which Donna Haraway (1995, 160-199) works with in her analyses and which both authors transport from a purely medical environment to a broader social and biopolitical one. Even though immunity has multiple meanings, in terms of the current topic there are two especially noteworthy medical aspects which reveal its potential for much broader analyses. First, it must be said that the immune system protects the body from harmful substances. ${ }^{11}$ When in direct contact with a foreign substance, it provokes an immune reaction which has the goal of eliminating the antigen. To achieve this, it uses an inborn form of defense, but can also, over the course of a lifetime, develop specialized forms of defense which develop in direct contact with various antigens, such as during sickness or vaccination. The primary function of the immune system is therefore to protect the body from foreign substances using a variety of defensive mechanisms. One part of this complex and varied system, however, is immunological tolerance. This is a specific suppression of the immune reaction, or a non-reaction, to those antigens that the body was exposed to during the embryonic stage. Following such prior contact to antigens, no immune reaction is triggered, because immune cells have learned to tolerate these antigens as if they were inherent to the body. ${ }^{12}$

The phenomenon of immunological tolerance is interesting because it shows that a system primarily focused on the protection of an organism from foreign substances is still capable of tolerating these substances under specific conditions. Tolerance is the act of acceptance and cordiality to what is different and foreign. If we return to the previously stated concerns that refined humans may increase discrimination against the non-refined, then besides the implementation of effective social and regulatory mechanisms, it will also be necessary to build and cultivate an environment of tolerance to those different from us. Ultimately, even Asimov hints at two possible approaches. One is the effort to eliminate what is different and remove the mutant. The other approach is coexistence with those different from us, a coexistence with the population of the Second Foundation. An environment of tolerance is exceptionally important and has to be cultivated regardless of whether transhumanist visions 
of human refinement are fulfilled or not. Already in today's society, we encounter human diversity, and these connections do not always pass without incident.

\section{CONCLUSION}

Mankind's ability to overcome the level of the empirical given is the key to interpreting many of its creations. From the fascination for scientific and technical knowledge, and fears of its possible consequences, human imagination and human rationality have managed to forge varied visions of the future. In science-fiction literature, we can find visions which develop the current form of understanding into literary imagery enhanced with fantasy and speculation. In the direction of plausible and realistic prognoses, visions that attempt to overstep the current level of understanding can be found in transhumanist discourse. Besides parallels relating to the visionary and subversive characters of the two discourses, the joint themes and motifs which they deal with are extremely important and thus present themselves for a more indepth analysis. Using selected motifs from the well-known Foundation series by Isaac Asimov, this article has given some detailed thought to big data analysis, which as a method is a chief moving factor in Asimov's literary storytelling and which spurs on developments in the fields of AI, which, according to transhumanists, will lead to the creation of superintelligence. Another common motif is the confrontation with beings with superhuman mental abilities. This confrontation is directly present in the science-fiction novel and also in transhumanist scenarios, and in both cases brings up multiple questions about mutual coexistence with those different from us. The search for answers to these questions are some of the most pressing for society today both from the viewpoint of possible dystopian futures as well as in terms of accepting the existing diversity of the present.

A parallel study of both discourses confirms that literary and transhumanist visions are now important impulses for societal, social, ethical, and anthropological analyses. The more complex the analyses, the easier it will be to devise strategies which will help mankind eliminate potential risks stemming from the application of technologies to humans.

\section{NOTES}

1 In the article, we use the term transhumanism as an extension of humanism. This is because the transhumanist vision of improvement and enhancement still applies to humans. The term transhumanism was chosen also in the light of the analyzed work by Isaac Asimov, which features the character of a mutant - a human with enhanced mental abilities.

2 On the occasion of Asimov's 100th birthday, the Lindeni publishing house in 2020 released a complete Slovak edition of Asimov's original Foundation trilogy (trans. by Patrick Frank). Until that point, only the first book had been available in Slovak translation (as Základňa, trans. by Dušan Slobodník in 1991).

3 See Nicholls and Ashley 2020.

${ }^{4}$ In his series on robots, Asimov devised the three laws of robotics. At the time, he differentiated himself from earlier narratives about robots such as that depicted in R.U.R. by Karel Čapek. See Horáková 2006, 71-80. 
5 See Sterling 1998-2020.

6 Mikhail M. Bakhtin (2008) analyzed the importance of the term chronotopos for literary storytelling.

7 See Stableford and Langford 2017.

8 The connection between the concepts of transhumanism and immortality is more closely analyzed by Odorčák 2019.

9 For connections to broad research in neurotechnology and neuroscience, see an analysis of aesthetic and emotional experience from a cognitive and neuroscience perspective (Démuth 2019; Démuthová 2019) as well as contemporary analyses of perceptual illusions (Ihringová 2019).

${ }^{10}$ See Waldenfels 2006.

${ }^{11}$ DocCheck Flexikon. Das Medizinlexikon zum Medmachen. Accessed December 14, 2020. https://flexikon.doccheck.com/de/Immunit\%C3\%A4t.

${ }^{12}$ Frank M. Burnet and Peter B. Medawar shared the 1960 Nobel Prize in Physiology or Medicine "for discovery of acquired immunological tolerance." See Universal-Lexikon. Accessed December 15, 2020. https://universal_lexikon.deacademic.com/271540/Medizinnobelpreis_1960\%3A_Frank_McFarlane_Burnet_\%E2\%80\%94_Peter_Bryan_Medawar.

\section{LITERATURE}

Allen, David L. 1977. On Asimov's Foundation Trilogy \& Other Works. Notes. Lincoln, NE: Cliffs Notes. Asimov, Isaac. 2010. Foundation. Foundation and Empire. Second Foundation. With an Introduction by Michael Dirda. New York, NY, London, and Toronto: Everyman's Library.

Bakhtin, Mikhail M. 2008. Chronotopos. Trans. by Michael Dewey. Frankfurt am Main: Suhrkamp.

Berry, David M. 2014. "Die Computerwende - Gedanken zu den Digital Humanities." In Big Data. Analysen zum digitalen Wandel von Wissen, Macht und Ökonomie, ed. by Ramón Reichert, 47-64. Bielefeld: Transcript Verlag. DOI: https://doi.org/10.14361/transcript.9783839425923.47.

Boellstorff, Tom. 2014. “Die Konstruktion von Big Data in der Theorie." In Big Data. Analysen zum digitalen Wandel von Wissen, Macht und Ökonomie, ed. by Ramón Reichert, 105-132. Bielefeld: Transcript Verlag. DOI: https://doi.org/10.14361/transcript.9783839425923.105.

Bostrom, Nick. 2018. Die Zukunft der Menschheit. Aufsätze. Trans. by Jan-Erik Strasser. Berlin: Suhrkamp Verlag.

Bostrom, Nick. 2020. Superintelligenz: Szenarien einer kommenden Revolution. Trans. by Jan-Erik Strasser. 4th edition. Berlin: Suhrkamp Verlag.

Deleuze, Gilles. 1993. Unterhandlungen 1972-1990. Trans. by Gustav Roßler. Frankfurt am Main: Suhrkamp Verlag.

Démuth, Andrej. 2019. Beauty, Aesthetic Experience, and Emotional Affective States. Berlin: Peter Lang. DOI: https://doi.org/10.3726/b15673.

Démuthová, Slávka. 2019. “Krása v kontexte evolučných prístupov." Filosofický časopis 67, 4: 591-604.

Esposito, Roberto. 2004. Immunitas: Schutz und Negation des Lebens. Trans. by Sabine Schulz. Zürich: Diaphanes.

Galloway, Alexander, and Eugene Thacker. 2014. "Protokoll, Kontrolle und Netzwerke." In Big Data. Analysen zum digitalen Wandel von Wissen, Macht und Ökonomie, ed. by Ramón Reichert, 289-312. Bielefeld: Transcript Verlag. DOI: https://doi.org/10.14361/transcript.9783839425923.289.

Gehlen, Arnold. 2009. Der Mensch: Seine Natur und seine Stellung in der Welt. 15st edition. Wiesbaden: Aula Verlag.

Haraway, Donna. 1995. "Die Biopolitik postmoderner Körper: Konstitutionen des Selbst im Diskurs des Immunsystems." In Die Neuerfindung der Natur: Primaten, Cyborgs und Frauen, ed. by Carmen Hammer and Immanuel Stieß, trans. by Immanuel Stieß, 160-199. Frankfurt am Main and New York, NY: Campus Verlag.

Horáková, Jana. 2006. “Jsem člověk, anebo jsem stroj?” Kritika \& Kontext 11, 32: 71-80.

Ihringová, Katarína. 2019. Ilúzia: Obraz ako metafora ludskej mysle. Bratislava: Veda, vydavatelstvo SAV. 
Kurzweil, Ray. 2016. Die Intelligenz der Evolution: Wenn Mensch und Computer verschmelzen. Trans. by Helmut Dierlamm, Enrico Heinemann, Ute Mihr, Thomas Pfeiffer, and Reiner Pfleiderer. Köln: Kiepenheuer \& Witsch Verlag.

Lacko, Ivan. 2020. "Ani úmysel, ani náhoda - skôr niečo medzi tým: Posthumanistické témy vo filme Ex Machina.” Filozofia 75, 2: 148-157. DOI: https://doi.org/10.31577/filozofia.2020.75.2.6.

Manovich, Lev. 2014. “Trending: Verheißungen und Herausforderungen der Big Social Data." In Big Data. Analysen zum digitalen Wandel von Wissen, Macht und Ökonomie, ed. by Ramón Reichert, 65-84. Bielefeld: Transcript Verlag. DOI: https://doi.org/10.14361/transcript.9783839425923.65.

Nicholls, Peter, and Mike Ashley. 2020. "Golden Age of SF." In The Encyclopedia of Science Fiction, ed. by John Clute, David Langford, Peter Nicholls, and Graham Sleight. Accessed December 10, 2020. http://www.sf-encyclopedia.com/entry/golden_age_of_sf.

Odorčák, Juraj. 2019. "Transhumanism and immortality." In Promises and perils of emerging technologies for human condition, ed. by Peter Sýkora, 65-82. Berlin: Peter Lang. DOI: https://doi.org/10.3726/ b15689.

Rawls, John B. 2007. Spravodlivost' ako férovost. Trans. by Richard Cedzo. Bratislava: Kalligram.

Rüster, Johannes. 2018. "Ist das Körper oder kann das weg? Transhumanismus zwischen Literatur, Mythos und Religion - und die didaktischen Konsequenzen." In Kritik des Transhumanismus: Über eine Ideologie der Optimierungsgesellschaft, ed. by Dierk Spreen, Bernd Flessner, Herbert M. Hurka, and Johannes Rüster, 143-174. Bielefeld: Transcript Verlag. DOI: https://doi.org/10.14361/9783839442876005.

Spreen, Dierk. 2018. "Politische Ökonomie nach dem Menschen: Die transhumane Herausforderung." In Kritik des Transhumanismus. Über eine Ideologie der Optimierungsgesellschaft, ed. by Dierk Spreen, Bernd Flessner, Herbert M. Hurka, and Johannes Rüster, 15-62. Bielefeld: Transcript Verlag. DOI: https://doi.org/10.14361/9783839442876-002.

Stableford, Brian M., and David Langford. "Galactic Empires." In The Encyclopedia of Science Fiction, ed. by John Clute, David Langford, Peter Nocholls, and Graham Sleight. Accessed December 10, 2020. http://www.sf-encyclopedia.com/entry/galactic_empires.

Sterling, Bruce. 1998-2020. "Science Fiction: Literature and Performance." Britannica.com. Accessed December 10, 2020. https://www.britannica.com/art/science-fiction/The-19th-and-early-20th-centuries.

Suwara, Bogumiła. 2016. “'Digiliteráti' verzus 'papieroliteráti' alebo transdisciplinárne dobrodružstvo.” World Literature Studies 8, 3: 90-103.

Sýkora, Peter. 2019. "K posthumánnemu človeku prostredníctvom editovania génov pre kognitívne schopnosti." Filozofia 74, 7: 511-529. DOI: https://doi.org/10.31577/filozofia.2019.74.7.1.

Waldenfels, Bernhard. 2006. Grundmotive einer Phänomenologie des Fremden. Frankfurt am Main: Suhrkamp Verlag. 
Science-fiction literature. Isaac Asimov. Transhumanism. Big data analysis. Artificial intelligence. Superintelligence. Coexistence. Diversity. Biotechnology.

The prerequisites for transhumanist visions can be identified on anthropological, social, scientific, and technological levels. But one cannot neglect science-fiction literature, which provides transhumanism with inspiration and literary imagery. This article focuses on three selected motifs in the well-known Foundation series by Isaac Asimov, which discusses in relation to ideas of transhumanism. In the first part, the article highlights the visionary and subversive character of these works and seeks similar traits in transhumanism. The second part discusses big data analysis, which is an important component of literary storytelling and which fuels the development of artificial intelligence, which, according to transhumanists, will lead to the creation of superintelligence. The third motif is the confrontation with beings that possess superhuman abilities, something both Asimov's work and transhumanist visions deal with and which opens up questions about coexistence with those who are unlike us. Literary and transhumanist visions have multiple parallels and encourage deeper social, ethical, and anthropological analyses of important topics.

Doc. Mgr. Jana Tomašovičová, PhD.

Centre for Bioethics

Department of Philosophy and Applied Philosophy

Faculty of Arts

University of Ss. Cyril and Methodius in Trnava

Nám. J. Herdu 2

91701 Trnava

Slovak Republic

jana.tomasovicova@ucm.sk

ORCID: https://orcid.org/0000-0002-4103-4608 